POLISH POLITICAL SCIENCE

VOL XLII 2013

PL ISSN 0208-7375

\title{
POLITICAL PARANOIA - A RULE OR A CHANCE?
}

\section{by Agnieszka Kasińska-Metryka, Rafał Miernik}

Politics is a particular field of social activity where accusing an opponent of mental incapacitation occurs as a frequent element of the conducted narrative. Moreover, public opinion discrediting a profession of a politician ${ }^{1}$ is very eager to question the mental health of political actors. Vocabulary used in the public is a vital testimony of societies attitude towards people with mental disorders. However, we refer paranoia to personality traits of individuals while political paranoia refers to reaction to events, facts or to the way it is seen by individuals or groups. The authors do not have any ambition to carry out a psychological analysis of politicians. What is intriguing is the issue of using political paranoia (searching for enemies, tracking plots, fighting in defence of ideals, irrational justification of failures) in the group spectrum for elections. What is also intrigu-

${ }^{1} \mathrm{~W}$ According to public opinion regarding professions with social trust only 1 percent of respondents said they trusted politicians (MPs, senators) See. OPINIA SPOŁECZNA NA TEMAT ZAWODÓW ZAUFANIA PUBLICZNEGO, Komunikat $\mathrm{z}$ badań CBOS, BS/73/2004. Also, repeated studies on prestigious professions show depreciation of the politician profession. In a survey conducted in 2009, the list of prestigious professions included: a governor, a minister, a councilman, an MP Deputy, a party activist. See PRESTIŻ ZAWODÓW, Komunikat $\mathrm{z}$ badań CBOS. 
ing is the answer to the question whether politicians are paranoid, or it is a well planned election strategy which aims to identify an opponent to consolidate a group of voters around the leader.

Research conducted by CBOS (Public Opinion Research Centre) in 2008 shows that not much has changed in the semantic issues since the first research in 1996. Pejorative terms that emphasise intellectual inferiority still prevail. ${ }^{2}$ This is due to numerous systemic and historical determinants, but is also due to society mentality and at the level of education in this field.

It can therefore be argued that calling some politicians „mentally ill” is for the majority of addressees a substitute for using invectives towards a disliked professional group. However, there is a part of society convinced that people involved in politics are of a psychological structure far from a so called norm. Nonetheless the above definitions do not have a basis in a sound psychological diagnosis, which is to identify the disorder, syndrome or state through a classification and categorisation of the observed behaviour of political scene actors ${ }^{3}$, and it is only a matter of interpretation of various behaviours compared to our own ones. Individuals therefore perceive politicians as "abnormal" and express their perceptions based on stereotypes in terms of $\mathrm{we}^{4}-$ good, they - bad ${ }^{5}$. This is defined as the perception of a mirror reflection ${ }^{6}$.

The second concept is shared by some researchers who deal with personality aspects of political psychology. Harold Lasswell in his book "Psychopathology and Politics"7 formulated a bold (though not expressed expresis verbis) thesis that all politicians are paranoid

2 See: OSOBY CHORE PSYCHICZNIE W SPOŁECZEŃSTWIE, Komunikat z badań CBOS, BS/124/2008.

3 See: P.G. Zimbardo, Psychologia i życie, Warszawa 1999, p. 627.

4 See: of "us" means a sense of connection between individuals in the same group. Positive distortion of the perception of the group is expressed in a tendency to favour its members. See W. Wosińska, Psychologia życia społecznego, Gdańsk 2004, p. 473

5 See also: My i Oni. Rola, miejsce i znacznie konfliktów w polityce, A. KasińskaMetryka, R. Miernik (ed.).

6 See: W. Wosińska, Psychologia życia społecznego, Gdańsk 2004, p. 525.

7 See: H. Lasswell, Psychopathology and Politics, Chicago-London 1930. 
A more balanced opinion was presented by a critical continuator of Lasswell's research - B. Rutherford, who considered paranoid personality as a typical type of political personality. It does not mean mental illness but only a significant disorder of personality function ${ }^{8}$. It depends on the occurrence of persistent delusional disorders (persecutory, grandiose, missionary, etc.) while maintaining a high level of intelligence, a contact with the surroundings, and a control of their own behaviour. Extensive analysis of political paranoia was presented by Robins and Post.

It shows that if specific characteristics of individuals find favourable conditions of politics, they develop into personality disorders as well. Obtained knowledge activates tendencies, which were previously subject to cultural and lifestyle restrictions ${ }^{9}$. Two aspects of paranoia can be pointed out. The first is the sense of danger in which the paranoid clearly specify the threats while the second is the activities of "conspiring forces” which cannot be fully explained due to them being conspired ${ }^{10}$. The political paranoids search for enemies responsible for collective misery, and whilst using social engineering methods they are able to maintain power in different stages of state development. At the same time they protect themselves from reality, which they do not accept, by creating their own supplementary reality which boosts their egos. The need to maintain that reality often requires them to present themselves as objects of conspiracy ${ }^{11}$ and under the influence of unknown forces located in the group "they - bad". For the paranoid, the enemy is clearly defined: He is a perfect model of malice, an amoral superman, who is sinister, ubiquitous, powerful, cruel, sensual and luxury -loving. The interpretation of history is clearly personal: decisive events are not regarded as a part of history but

8 See: Z.J. Pietraś, Decydowanie..., op.cit. p. 336.

9 German psychiatrist Ernest Kretschmer claimed that in the troubled times we are ruled by psychopaths, in the times of peace we judge them. However, in practice in the times of peace those who rule us are not normal either (translator's note). Taken from M. Krzymowski, G. Łakomski, Zdeprawowani władza, "Wprost”,12.07.2009, No. 28, p. $10-12$.

10 Compare Korzeniowski, p. 73.

11 R.S. Robins, J.M. Post, Paranoja polityczna. Psychologia nienawiści, Warszawa 1999, p. 29 . 
as a consequence of someone's will. The enemy very often has some effective source of power: he controls the press, has funds, and knows a new secret method influencing people because has a special technique of seduction ${ }^{12}$. Very often, the enemy is held to possess some especially effective source of power: he controls the press; he has unlimited funds; he has a new secret for influencing the mind (brainwashing ); he has a special technique for seduction (the Catholic confessional). [ 1 ]

On the other hand, politicians' attitude and their mental state release similar reactions in the ruled society. Verbal attacks, physical aggression, anonymous letters, threats are a part of politics initiated by disappointed and frustrated individuals or groups because of them being ignored. Such behaviours create an atmosphere prone to populism, and they may even escalate, leading to radical, rapid changes of the system and to the emergence of new leaders. Moreover, since 2010 it has been noticed in Poland a clash of two groups - first, gathered around Solidarni 2010, and the second, which does not believe in the so-called "Smolensk conspiracy". The former are convinced of their rightness of their beliefs and of their moral superiority. B. Wojciszke defined such manifesting tendency of the group representing views of the minority as millitant minority syndrome, whilst noting that this syndrome is dangerous in the society of a fragile democracy as it blocks minorities of extreme views from reaching an agreement with the majority. Conviction in morality in turn provokes an escalation of the conflict and it stiffens the already uncompromising standpoint ${ }^{13}$. Belief in one's own infallibility and trueness of one's theories (including conspiracy theories), that is crowd paranoia, not only creates frustrations and hostility, but also leads to the escalation of social conflicts. The danger of conflict escalations increases when a leader emerges from the crowd, a leader who is capable of not only making a "delusion" more reliable but also assures the group of the trueness and rationality of the

12 See: R. Hofstader, Paranoid style in american politics, "Harper Magazine", 11.1964, p. $77-86$.

13 See: B. Wojciszke, The consequences of being an influential minority in the context of social controversies in the emerging Polish democracy, [in:] W. Wosińska, R.B. Cialdini, D.W. Barett, J. Reykowski (eds.), The practise of social influence in multiple cultures, New Jersey 2001, p. 173-188. 
proclaimed views. According to Gustav le Bon, the leader is initially a part of a crowd, and first he needs to be enchanted by some idea before he becomes its propagator.,Przywódcami tłumu są najczęściej ludzie czynu, nie zaś myśliciele (...) Przywódcami tłumu stają się też ludzie o starganych nerwach lub na pół obłąkani, którym niedaleko jest do zupełnego obłędu"14 (The leaders of the crowds are mostly men of action, not thinkers. The leaders of the crowd are also people with jagged nerves or half-insane, who are close to complete insanity, translator's note).

Former USA National Security Advisor Zbigniew Brzezinski even states that the twentieth century was dominated by „politics of organised insanity” 15 . In „Faces of the Enemy” S. Keen coins the term „consensual paranoia"16. Propaganda proclaiming the existence of the enemy using peoples' loyalty and identification with their own nation can make them feel insecure, vulnerable and prone to paranoia ${ }^{17}$. It seemed that the end of the Cold War and the fall of the Berlin Wall would make „the paranoia blow away". However, it is increasingly more evident that through inducing permanent insecurity, fear, and the search for the enemy whereby the paranoia has moved from the sphere of pathology to the sphere of logical and reasonable action, which adds to its credibility ${ }^{18}$.

If, therefore we assume that paranoia is a set of systematised delusions (judgements) which do not change personality structures we can say that on the basis of a symbiotic system it applies to both politicians and the electorate "infected" by the political judgements formulated by the leader. Democracy in the light of camera, or so called media democracy serves untypical behaviours as they often have a theatricalisation value of political issues, and thus are willingly broadcast in the media. Props, organisation of political happenings, reports from politicians' private lives

14 As above, p. 377-378.

15 Following: R. Koenigsberg, Political violence and concept of collective psychopathology, "Library of Social Science" 2008, p. 1.

16 S. Keen, Faces Of The Enemy, New York 1987, p. 11.

17 O. Zur, Love of hating. The psychology of Enmity, "History of European Ideas" 2012 13(04), p. 345.

18 W. Hui Kyong Chun, Control and freedom. Power and paranoia in the Age of Fiber Optics, Cambridge-London 2006, p. 1. 
are some of the examples of political marketing. Scandal, untypical behaviours, blogs attract media attention more effectively than any thorough political debate. Politicians become celebrities, who evoke extreme emotions - supporters treat them as close friends while opponents perceive them as enemies. For the receiver of the information, the media experience is secondary and it often blurs the sense of distance and rational assessment. People - as it was noted by J. Magee - tend to strive not only to power but also to contacts with people in power. This way creates or even provokes situations in which it is easier to exceed accepted standards such as sexual ones (for example so called "sex scandal" in Samoobrona). Power enables to fulfil desires because politicians are deprived of restrictions typical for common people $e^{19}$. According to the researcher cited people with power differ from the rest of society by two crucial dimensions, i.e. they are more extroverted and more sociable. They, to a greater extent, feel the need to have control over the community, and power provides the necessary tools required to achieve it. To a greater extent they feel the need to have control over the environment, and the necessary instruments for this purpose is just power. Also, experiments have shown that people who do not even have real power (test groups are divided into "the rulers" and "the ruled") behave in such a manner as if they had.

Methodological backgrounds are a significant barrier to mental health diagnosis of political elites; however, progress can be noticed in this mat$\operatorname{ter}^{20}$. At the level of both verbal and non-verbal analysis of politicians' behaviour we can observe signs of emotional problems and of strong internalisation of social roles ${ }^{21}$. A key question therefore arises, whether

19 Władza odsłania prawdę. A talk between A. Postoł and prof. J. Magee, "Wprost", 12.07.2009, p. 12-13.

20 According to some studies, 70 percent of people holding managerial positions in business is called alpha personality. Some of them - according to American psychiatrists R. Hare i P. Babiak - are personalities on the verge of accepted norm or even psychopaths. I. Dominik, D. Malesa, Mój szef psychopata, "Newsweek", 5.01.2009.

21 Analysis of leadership biographies confirms that many of the leaders are prone to exaggerated emotional expression. M. Luter, T. Roosvelt, B. Mussolini, and W. Churchill are some of the people affected by bipolar disorder. It is associated with mood swings that range from hypomania to manic - depressive psychosis with cyclothymic disorder in between. The leaders with bipolar disorder are characterised by oexistence of extreme 
individuals who go into politics are different in their perception of reality, or whether a political scene predestines to have such personality traits developed that are considered to be dysfunctional. Synoptic studies of great leaders allow us to draw a conclusion that it is mostly environmental conditions fostering decision-making or breaking the rules in the unconventional way. A striking confirmation of this thesis are the words of two historically distant leaders, yet still connected by the explantation of their activities „Chciałem panowania nad światem - $i k t o ́ z ́$ by nie chciat na moim miejscu? Świat mnie sam zapraszał do rządzenia, władcy i poddani śpieszyli z ochotą pod moje berło" (I wanted to rule the world, and who would not want to in my place? I was invited to rule the world itself, rulers and the subjects hurried eagerly into my sceptre, $\mathrm{TN})^{22}$. This sentence uttered by Napoleon Bonaparte is in its essence consistent with a statement made by B. Clinton, who while explaining the circumstances of the affair with M. Lewinsky, he confessed: „Powód, dla którego to zrobiłem, był najgorszy z możliwych. Zrobiłem to, bo mogłem". (The reason why I did it, it was the worst possible. I did it because I could, TN) ${ }^{23}$.

Thus, what activates leaders' personality disorders? Researchers mention here narcissism, tendency to paranoia, frustration leading to aggression ${ }^{24}$. The existing studies refer mainly to historical figures; however current analysis of political life also provides many examples of actions on the verge of emotional balance. With regard to the Polish political scene we can mention politicians involved in sex scandas, alcohol abuse, drugs, and belief in the existence of conspiracies, being intercepted or under surveillance.

According to the researchers, some politicians represent anti-social personalities. The above type of personality appears among those in power

\footnotetext{
behaviours - on one hand they are in a good mood, on the other they feel empty and lonely. M. Kets de Vries, Mistyka przywództwa. Wiodace zachowania w przedsiębiorczości, Warszawa 2008, p. 60-61.

22 J. Baszkiewicz, Anatomia bonapartyzmu, Gdańsk 2003, p. 164.

23 Following M. Krzymowski, G. Łakomski, Zdeprawowani władzą, "Wprost" 12.07.2013, No. 28, p. 10-12.

24 W. Markiewicz, Krew wypije, a dziurki nie zrobi, "Polityka”, 15.03.2008, No. 11, p. 104 .
} 
more often than in other professions and is characterised by emotional immaturity, notorious lying, the inability to listen to others' arguments and at the same time appealing to the lowest human emotions. Other disorders common among people in power are already mentioned narcissistic and paranoid personalities, as well as obsessive - compulsive personality disorders and passive-aggressive personalities. Narcissism is characterised by the exaggerated sense of self importance, a tendency to overestimate one's actual achievements, unreasonable belief of being special, an exhibitionist needs to gain attention and admiration, a lack of empathy and also inadequate emotional reactions to criticism from others ${ }^{25}$. Politicians with this kind of personality disorder in order to avoid being accused of egocentrism overuse plural numbers and instead of saying „I have achieved a lot" say „we have achieved a lot". At the same time he is characterised by a lack of empathy and trust toward the surroundings.

The other disorder, i.e. obsessive - compulsive disorder is manifested by excessive preoccupation with details, rules, and order. Other typical characteristics are, just to name a few, submission to convention, a liking for formality, statements containing in-depth analysis, useless details and excess of information used to create chaos of communication. As far as the above mentioned personality type can slow down the decision-making processes then the politician with passive-aggressive disorder is capable of blocking them. He presents his own inabilities as merits which require appreciation, and towards community he adopts a stance of criticism and contempt. If such an individual holds a managerial position, he usually delays fulfilment of any important tasks expected by colleagues. The best described disorder with respect to politics is, among the above-mentioned disorders, a paranoid disorder ${ }^{26}$. This personality dysfunction is manifested by excessive suspicion, hostility, and sensitivity to any accusations. Other features of paranoid personalities are: distrust, vigilance, cynicism, competition, resentment, jealousy, hypersensitivity to criticism, anger, vindictiveness, caution, arrogance, and a tendency towards arbitrariness and

25 See: Narcissistic Personality Disorder Symptoms. http://psychcentral.com/disorders/ sx36.htm, 03.07.2009.

26 See K. Korzeniowski, Polska paranoja polityczna. Źródła, mechanizmy i konsekwencje spiskowego myślenia o polityce, Warszawa 2010. 
despotism ${ }^{27}$ etc. These types of disorders may coexist, and under the conditions of stress and fatigue they can develop into paranoia, depression, schizophrenia or mania ${ }^{28}$.

In fact, the whole period of political transformations in Poland provides examples of political behaviours with the attributes of paranoia. Lech Walesa was in the habit of personal control over people being late to the office and giving them verbal reprimands. Lech Kaczyński was convinced that some unexplained "coincidences" were happening in order to marginalise the role of him and his brother in bringing about the fall of communism. „Pamiętam, jak wychodziliśmy ze stoczni trzymając się z bratem pod ręce, ale - co charakterystyczne - potem na żadnych zdjęciach z tego marszu nie było nas widać" twierdził były prezydent. Katarzyna Piekarska admits that she checks each party or constituency office in search of bugs, according to Zbigniew Ziobro, his phone records are constantly being checked. Also, MP Macierewicz mentions he is strongly convinced about external spheres of political influence ${ }^{29}$.

J. Palikot in Kulisach Platformy claims, that Grzegorz Schetyna was close to conspiracy theories ${ }^{30}$ and used special services and prosecution for political purposes. Palikot has not caught Schetyna red handed but he is more than certain about it ${ }^{31}$. Also, he suggests that Donald Tusk's decisions

27 R.S. Robins and J.M. Post singled out seven elements characterising paranoid mind: Suspicion, selfishness, megalomania, hostility, fear of loss of independence, projection, delusional thinking.

28 A. Chodubski prepared a comprehensive overview of the psychohistoric determinants of the leadership He analysed the role of neurasthenics in the history of civilisation. Starting from biblical times to the twentieth century he proved that the desire for power in neurasthenic individuals is a result of weakness. People with mental disorders escape from the world and "hide" in politics. There they can see the opportunity to free themselves from daily routines and to realise individual or collective purposes. See A. Chodubski, Uwarunkowania psychohistoryczne i kulturowe przywództwa, [in:] Przywództwo polityczne, ed. T. Bodio, Warszawa 2001, p. 320-340.

29 See: M. Krzymowski, G. Łakomski, Zdeprawowani władza, "Wprost" 12.07.2009, No. 28, p. 10-12.

30 Kulisy Platformy, A. Wojciechowska’s interview with J. Palikot, Warszawa 2001, p. 17.

31 Ibidem, p. 44. 
on what law to make, what needs to be touched and what to be covered are based on what is in the tabloids ${ }^{32}$.

Research that has been conducted since the end of the 90's shows a gradual increase in a conspiratorial perception of politics which may be the result of the historical past (partitions, military occupation, communism), of very low social trust, and of a lack of rules towards political correctness according to which it is unbecoming to talk openly about conspiracies or connections which govern the country ${ }^{33}$.

What is crucial in this subject matter is to focus on research dealing with the variability of the increasing political paranoia using the Political Paranoia Scale during national elections ${ }^{34}$. The results of cited studies indicate a high level of political paranoia before the election, while shortly after, and four weeks after the elections, political paranoia remained at a lower level. Before the election, the political paranoia is a less coherent, disordered phenomenon, and its structure changes during the election period, when it becomes a one-dimensional and an internally consistent phenomenon ${ }^{35}$. D. Pigla reached similar conclusions during the EU accession referendum. Two months before the event the intensification of political paranoia was much higher than in the week of just after the referendum and two months after it. Apart from the impact of a number of variables such as environmental factors, wealth, and education of parents it can be argued that from the point of political marketing the level of political paranoia may also be influenced by those marketing operations conducted by political actors. Aforementioned problem requires a detailed study of political scientists in collaboration with psychologists, political scientists, sociologists, culture experts, however it is worth looking at some of the slogans proclaimed during the elections and the accession referendum. What requires special attention is the possibility to use rhetoric to „evoke" political paranoia and translate it into the results of an election, and the mobilisation of the electorate. Proclaim-

\footnotetext{
32 Ibidem, p. 210.

33 M. Krzymowski, G. Łakomski, op.cit.

34 See: M. Osiecka, Wybory prezydenckie a zmienność paranoi politycznej, Warszawa 2002

35 K. Korzeniowski, op.cit., p. 107-108.
} 
ing the slogans of the existing agreement, secret services, the criminal low-life, some politicians (liberal and communist) and the business community has become a weapon of political struggle especially for the right-wing parties ${ }^{36}$. The slogan Fight with the system is, according to PiS (Prawo i Sprawiedliwosc - Law and Justice party, TN) supporters, an attempt to purify the political apparatus from the omnipresent corruption and to prevent operations and activities harmful to Poland. Opponents and critics claim that this resembles the communist slogan who is not with us is against us, and it is more a way to gain favour with the public than a way to improve the political and economic situation in Poland. Kaczynski even claimed that scientific studies are conducted to show the relationships between the various centres of power in Poland by using a model of a computer system ${ }^{37}$.

The answer to the question of whether the paranoid slogans and behaviours are a problem which should be dealt with by psychiatry, or whether they are perhaps only the "election traps", is extremely difficult from a methodological point of view, yet it arouses the authors' scientific curiosity. In order to avoid speculation and making a cognitive mistake, it can be established that on the basis of election results the paranoid rhetoric has had largely positive effects. The agitation it brings in some social groups gives rise to them being strongly equated with the leaders and with their slogans, which might be only election slogans.

In conclusion, the ease with which a paranoid perception of reality by politicians undergoes a move into a society should be noted. Paranoia as a "disease of intellect" depends on the correct reception of information yet it involves a specific processing, i.e. based on the schematisation of us vs. them. Unusual events, information overload and difficulties in finding a rational explanation all contribute to paranoid thinking. As noted by Krzysztof Korzeniowski „the more democracy, the more paranoia among

36 See: Czas na zmiany: z Jarosławem Kaczyńskim rozmawiaja Michał Bichniewicz i Piotr M. Rudnicki, Warszawa 1993.

37 Interview conducted on $28^{\text {th }}$ August 2007 by Jacek Deptuła for Gazeta Pomorska. “Gazeta Pomorska”, 31.08.2007. 
people"38. From the ancient period we have examples of such rulers as Caligula and Julius Caesar who indulged in spectacular forms of expressing their political ideas, but in the "system" sense it was the times of the French revolution which initiated conspiracy theories as an element of social mentality. The division of authority contributed to the increase in the complexity of the political system, and thus increased the difficulty in understanding the rules governing it. Whilst the monarch's power was understandable for subjects as he was the only source of regulation, implementation and enforcement of the law, the tripartite division of power and an increased role of the media as an interpreter of politics caused explanatory difficulties. Paranoid thinking can be considered a factor that may jeopardise the democratic system. If a threshold of paranoid thinking is extended we may experience political upheaval, (see: effects of paranoid message of A. Hitler). In order to determine the threshold we use the poll which evaluates the level of radicalism and belief in the "external control centre." Paranoid leadership implies a specific type of social behaviour, but the impact of this has a two-way character - the suspicious society, looking for the enemy, prone to conspiracy theories, elect such leaders who provide a simple interpretation of the complex political reality.

38 K. Korzeniowski, „Polskie paranoje”. Psycholog o obrońcach krzyża i teoriach spiskowych, http://spoleczenstwo.newsweek.pl/-polskie-paranoje---psycholog-o-obroncach-krzyza-i-teoriach-spiskowych,63539,4,1.html, 23 IX 2011 r. 